\title{
The clinical study of vaginal birth after caesarean section
}

\author{
Amarpali K. Shivanna ${ }^{1}$, Spandana S. ${ }^{1 *}$, Rajani Vaidya ${ }^{2}$
}

\begin{abstract}
${ }^{1}$ Department of Obstetrics and Gynecology, DM Wayanad Institute of Medical Sciences, Meppadi, Kerala, India
${ }^{2}$ Department of Obstetrics and Gynecology, Malbar Medical College and Hospital, Ulliyeri, Kozhikode, Kerala, India
\end{abstract}

Received: 23 October 2020

Accepted: 29 October 2020

*Correspondence:

Dr. Spandana S.,

E-mail: spandana.subbegowda@gmail.com

Copyright: () the author(s), publisher and licensee Medip Academy. This is an open-access article distributed under the terms of the Creative Commons Attribution Non-Commercial License, which permits unrestricted non-commercial use, distribution, and reproduction in any medium, provided the original work is properly cited.

\begin{abstract}
Background: VBAC has reduced the rate of repeat caesarean section in modern medicine. VBAC-TOL is successful in $60-80 \%$ of acceptable candidates if applied to all patients presenting with prior caesarean procedure $(8.2-8.5 \%)$, there is potential to increase the overall vaginal delivery rate by $5 \%$. Though the safety of VBAC in carefully selected patients have been demonstrated in several studies, controversy continues over when to advise patients who had caesarean section to undergo TOL. The purpose of current study was to know the success of VBAC, to know the maternal morbidity and mortality and foetal outcome in VBAC group.

Methods: It was a prospective study performed on women with one previous LSCS admitted to tertiary care hospital for a period of one year from August 2018 to August 2019 at DM Waynad institute of medical sciences, Waynad.

Results: In the present study 292 women with one previous LSCS were selected, among them 32 women had elective LSCS for various indications, 260 women underwent TOL. Among 260 women, 152 women achieved VBAC $(58.46 \%)$ and 108 women underwent LSCS following failed TOL. Maternal morbidity was $9.61 \%$. The incidence of scar dehiscence was $2.69 \%$ and uterine rupture was $0.38 \%$. There was no maternal and foetal mortality in this study. NICU admission was $4.6 \%$.

Conclusions: Trial of labour should be encouraged in women with one previous LSCS with no obstetric complications.
\end{abstract}

Keywords: Trial of labour, Vaginal birth after caesarean section, Lower segment caesarean section

\section{INTRODUCTION}

With the increasing safety of modern anaesthesia and blood transfusion caesarean sections are being performed for not only contracted pelvis, dystocia, major degrees of placenta previa and severe eclampsia with a view to decrease maternal mortality but also has been extended for foetal indications like foetal distress, BOH, VLBW babies, breech presentation and as a safer alternative to difficult operative delivery to reduce perinatal mortality. Besides there have been numerous other obstetric, medical, social, ethical, economic and medico legal factors which have added to the list of indications leading to alarmingly high rates of caesarean sections all over the world. ${ }^{1}$

The pronouncement made by Dr. Edward Craigin in 1915; once a caesarean always a caesarean established elective repeat caesarean section as the standard of care in united states. ${ }^{2}$ With the changes in type of uterine incision, foetal monitoring techniques as well as improvement in anaesthesia blood banking and antibiotic have led to a reappraisal of his initial dictum, once a caesarean section always a hospital delivery. ${ }^{3}$ Hence presently Craigin's dictum needs to be modified. The present day dictum revolves around the optimal management after a previous caesarean delivery. ${ }^{4}$ The 
increase in caesarean section rate has drawn the alteration causing a reappraisal of standard practice of elective repeat caesarean section.

The first lower segment operation was performed by Kehrer on 25th September 1881. But it took many years that great advance came to be generally recognised and accepted. ${ }^{2}$ The largest boost for advocates of vaginal birth after caesarean section (VBAC) came from introduction of low transverse uterine incision by Kerr in 1926. whereas repeat caesarean was the American method of choice, a trial of labour (TOL) after previous Lower segment caesarean section (LSCS) was common practice in Europe in 1930s and 1970s.

Revised National guidelines suggested more stringent facility and personnel requirements in order to conduct vaginal delivery following previous caesarean section.

\section{VBAC recommendations by $A C O G^{3}$}

Selection criteria; one or two prior low transverse caesarean deliveries, clinically adequate pelvis, no other uterine scars or previous rupture, physician immediately available throughout active labour capable of monitoring labour and performing an emergency caesarean delivery, availability of anaesthesia and personnel for emergency caesarean delivery.

TOL is contraindicated when there is previous classical or $\mathrm{T}$ shaped incision or extensive trans fundal uterine surgery, previous uterine rupture, presence of contraindication to labour-medical or obstetric complications, inability to perform caesarean section because of unavailable surgeon or anaesthesia.,

VBAC-TOL is successful in 60-80\% of acceptable candidates if applied to all patients presenting with prior caesarean procedure $(8.2-8.5 \%)$, there is potential to increase the overall vaginal delivery rate by $5 \%$. There is evidence from large multicentre trails that VBAC-TOL reduces incidence of postpartum transfusion and duration of stay. The associated perinatal mortality rate $(7$ per 1000 live births) of the VBAC-TOL group is not higher than that of the overall rate (10.1 per 1000 live births). ${ }^{6}$ Though the safety of VBAC in carefully selected patients have been demonstrated In several studies, controversy continues over when to advise patients who had caesarean section to undergo TOL.

\section{METHODS}

Current study was a prospective study for one year from August 2018 to August 2019 at DM Waynad institute of medical sciences which is a tertiary care teaching hospital. A total of 292 Cases which were admitted during the study period for the purpose of labour were included in the study.

\section{Inclusion criteria}

This study included women with one previous LSCS at term or near term with singleton vertex presentation with no obvious obstetrical complications. 292 cases admitted to the labour ward or antenatal ward with one previous LSCS admitted for safe confinement were selected. Out of these 292 cases, 32 cases had elective repeat caesarean section and 260 cases were allowed for TOL. Among these 260 cases few who had failed TOL were taken for LSCS for various indications.

All the study subjects were analysed in full details regarding age, parity, previous obstetric performance including the number of vaginal deliveries prior to this pregnancy, indication for LSCS, institution where LSCS was done, history of any intraoperative and postoperative complications was noted. Regarding present pregnancy details of number of antenatal visits, any antepartum complications, menstrual history were noted, a thorough general, physical, systemic obstetric examination was done.

Women booked in antenatal clinic routine investigation was done. Patients allowed for TOL were carefully monitored for any signs of impending rupture. Electronic cardiotocograph was used. Progress of labour was noted. Labour was accelerated with artificial rupture of membranes in active labour whenever required. Oxytocin was used for acceleration of labour. In the third stage routine scar exploration was done. When the cervix was unfavourable induction was done with Foley's insertion followed by oxytocin augmentation 24 hours later.

Few cases who had undergone TOL required repeat LSCS due to various indications. In case where rupture was suspected TOL was immediately abandoned and taken for emergency laparotomy and necessary steps were taken. In cases that had undergone repeat LSCS after failed TOL, the indications for LSCS, intraoperative and postoperative details were noted. In all cases maternal and immediate foetal outcomes were noted. To know the foetal and maternal outcome in VBAC group it was compared with TOL-LSCS group.

\section{Statistical analysis}

Data entry was done in Microsoft excel sheet. Statistical significance was found using Chi square test.

\section{RESULTS}

Current prospective study was carried out in the department of obstetrics and gynaecology at a tertiary care teaching hospital over a period of one year. Total number of deliveries including LSCS is 2882. Total number of caesarean deliveries is 554 (19.22\%). Among the total number of women with caesarean sections (554), incidence of repeat LSCS was $4.8 \%$ (140). 
In this study the total number of women underwent TOL were 260. Among them VBAC success rate was 152 $(58.46 \%)$, failed TOL rate was $108(41.54 \%)$. Majority of women in the study group belonged to $20-30 y$ rs $(88.45 \%)$ and majority of cases are 2nd gravida $(53.84 \%)$.

Table 1: Depicting incidence of LSCS during study period.

\begin{tabular}{|llll|}
\hline $\begin{array}{l}\text { Total no. } \\
\text { of } \\
\text { deliveries } \\
\text { including } \\
\text { LSCS }\end{array}$ & $\begin{array}{l}\text { Total no. of } \\
\text { vaginal } \\
\text { deliveries }\end{array}$ & $\begin{array}{l}\text { Total no. of } \\
\text { caesarean } \\
\text { sections }\end{array}$ & $\begin{array}{l}\text { Incidence } \\
\text { of LSCS }\end{array}$ \\
\hline 2882 & 2328 & 554 & $19.22 \%$ \\
\hline
\end{tabular}

Table 2: Depicting Incidence of repeat LSCS during study period.

\begin{tabular}{|llll|}
\hline $\begin{array}{l}\text { Total no. } \\
\text { of } \\
\text { deliveries } \\
\text { including }\end{array}$ & $\begin{array}{l}\text { Total no. of } \\
\text { caesarean } \\
\text { deliveries }\end{array}$ & $\begin{array}{l}\text { Total no. } \\
\text { of repeat } \\
\text { LSCS }\end{array}$ & $\begin{array}{l}\text { Incidence } \\
\text { of repeat } \\
\text { LSCS }\end{array}$ \\
\hline 2882 & 554 & 140 & $4.8 \%$ \\
\hline
\end{tabular}

Table 3: Depicting success rate of VBAC.

\begin{tabular}{|c|c|c|}
\hline $\begin{array}{l}\text { Total cases } \\
\text { undergoing TOL }\end{array}$ & $\begin{array}{l}\text { Total no. of } \\
\text { VBAC }\end{array}$ & $\begin{array}{l}\text { VBAC success } \\
\text { rate }\end{array}$ \\
\hline 260 & 152 & $58.46 \%$ \\
\hline $80 \%$ & & \multirow{10}{*}{$\begin{array}{l}=\text { VBAC } \\
=\text { TOL- LSCS }\end{array}$} \\
\hline $70 \%$ & & \\
\hline $60 \%$ & & \\
\hline $50 \%$ & & \\
\hline $40 \%$ & & \\
\hline $30 \%$ & & \\
\hline $20 \%$ & & \\
\hline $10 \%$ & & \\
\hline $20-25$ & $26-30$ & \\
\hline Years Years & Years Years & \\
\hline
\end{tabular}

Figure 1: Comparison of age wise success rate of VBAC and TOL-LSCS.

In current study group, age wise comparison showed VBAC having high success rate (20-25 years, $57.14 \%$, 26-30 years, $61.11 \%, 31-35$ years, $54.16 \%$, >36 years, $75.00 \%$ ) against TOL-LSCS among all age groups except in <19 years old females having equal success rate (50 $\%)$. $30 \%$ of cases (78) had previous vaginal delivery, among them $79.48 \%$ (62) had successful VBAC and $20.51 \%$ (16) underwent LSCS. $70 \%$ of cases (182) didn't had previous vaginal delivery, among them $49.45 \%$ (90) had successful VBAC and 50.54\% (92) underwent LSCS.
Total of $92.69 \%$ babies had APGAR of >7, 2 babies had APGAR score between 0-3, one delivered by VBAC and one by LSCS, 17 babies had APGAR between 4-6, among them $64.70 \%$ delivered by TOL-LSCS and $35.29 \%$ by VBAC. NICU admission in TOL group was $8.07 \%$. No neonatal mortality was noted.

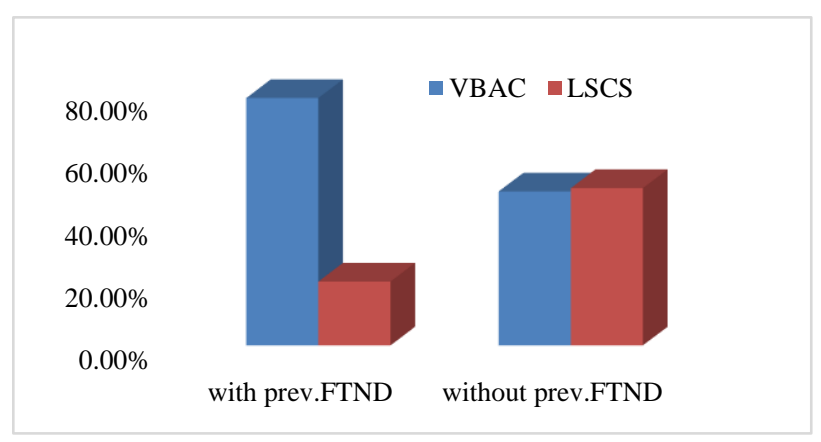

Figure 2: Comparison of VBAC success rate with previous vaginal delivery.

Maternal morbidity was $9.61 \%$ in TOL group. In that maternal morbidity was high in TOL-LSCS group $(12.96 \%)$, VBAC $(7.23 \%)$ group. In VBAC group there were 5 suspected scar dehiscence and all were managed conservatively. No maternal mortality in the study group.

Table 6: Depicting immediate fetal morbidity, NICU admissions.

\begin{tabular}{|ll|}
\hline NICU admissions & N $(\%)$ \\
\hline Total & $21(8.07)$ \\
\hline VBAC & $9(42.85)$ \\
\hline TOL-LSCS & $12(57.14)$ \\
\hline
\end{tabular}

Table 7: Comparision of maternal morbidity between VBAC and TOL-LSCS.

\begin{tabular}{|lllll|}
\hline & VBAC & $\%$ & $\begin{array}{l}\text { TOL- } \\
\text { LSCS }\end{array}$ & $\%$ \\
\hline PPH & 5 & 55.55 & 4 & 44.44 \\
\hline $\begin{array}{l}\text { Febrile } \\
\text { morbidity }\end{array}$ & 1 & 50 & 1 & 50 \\
\hline Ut. rupture & - & - & 1 & 100 \\
\hline $\begin{array}{l}\text { Scar } \\
\text { dehiscence }\end{array}$ & 5 & 41.66 & 7 & 58.33 \\
\hline $\begin{array}{l}\text { Wound } \\
\text { infection }\end{array}$ & - & - & 1 & 100 \\
\hline
\end{tabular}

\section{DISCUSSION}

The study was carried out to analyse the success rate of VBAC, to assess the maternal and foetal morbidity and mortality in VBAC group. In the present study VBAC success rate was $58.46 \%$, most of the studies reported success rate between $40-65 \% .^{7-10}$

In the present study it was found that $\mathrm{H} / \mathrm{O}$ previous vaginal delivery improved the chances of achieving 
VBAC. The order of previous vaginal birth did not significantly contribute to successful VBAC in present pregnancy. The result of the present study can be compared with Iyer et al $84.8 \%$ before caesarean section, $84.8 \%$ after caesarean section and Elkousy et al reported $83 \%$ before caesarean section and $94 \%$ after caesarean section. ${ }^{10,11}$ In present study $77.77 \%$ before caesarean section and $80.39 \%$ after caesarean section.

Table 8: Comparison of VBAC success rate in various studies.

\begin{tabular}{|ll|}
\hline Study authors & Success rate (\%) \\
\hline${\text { Demianczuk et } \mathbf{~ a l}^{\mathbf{7}}}^{\text {Martin et al }^{\mathbf{9}}}$ & 54.3 \\
\hline Iyer et al $^{\mathbf{1 0}}$ & 62.34 \\
\hline Agarwal et al $^{\mathbf{8}}$ & 43.40 \\
\hline Current study & 63.83 \\
\hline
\end{tabular}

In current study maternal morbidity was least in VBAC $(7.32 \%)$ group, maternal morbidity was more in TOLLSCS (12.96\%) group but this is not statistically significant $(\mathrm{p}=0.23)$ in present study. ${ }^{6,12,13-15}$

Table 9: Maternal morbidity.

\begin{tabular}{|llll|}
\hline & $\begin{array}{l}\text { Total } \\
\text { morbidity } \\
\text { TOL }(\%)\end{array}$ & $\begin{array}{l}\text { TOL- } \\
\text { LSCS } \\
(\%)\end{array}$ & $\begin{array}{l}\text { VBAC } \\
(\%)\end{array}$ \\
\hline Dickinson et al $^{\mathbf{6}}$ & 9.60 & 27.10 & 3.40 \\
\hline Hibbard et al $^{\mathbf{1 2}}$ & 13.6 & 27.40 & 6.30 \\
\hline Ladon et al $^{\mathbf{1 3}}$ & - & 17.00 & 2.60 \\
\hline Present study $^{\text {Pod }}$ & 9.61 & 12.96 & 7.23 \\
\hline
\end{tabular}

The incidence of scar dehiscence in present study was $2.69 \%$. The incidence of uterine rupture was $0.38 \% .{ }^{16}$ In the present study there was no maternal mortality and no foetal mortality. In this study 19 cases who had APGAR $<7$, out of which $12(11.11 \%)$ was found in failed TOLLSCS group. Most of the babies had APGAR score between 7-10 in the present study (92.69\%).

Table 10: Incidence of scar separation in the TOL group.

\begin{tabular}{|llll|}
\hline & $\begin{array}{l}\text { Dickinson } \\
\text { et } \mathbf{a l}^{6}\end{array}$ & Iyer et al ${ }^{10}$ & $\begin{array}{l}\text { Present } \\
\text { study }\end{array}$ \\
\hline $\begin{array}{l}\text { Scar } \\
\text { dehiscence }\end{array}$ & $1.10 \%$ & $1.50 \%$ & $2.69 \%$ \\
\hline $\begin{array}{l}\text { Rupture } \\
\text { uterus }\end{array}$ & $0.7 \%$ & $0.49 \%$ & $0.38 \%$ \\
\hline
\end{tabular}

In the present study the overall foetal morbidity in terms of NICU admission, special care, birth asphyxia and mild to moderate respiratory distress were higher in the TOLLSCS $(11.11 \%)$ group in comparison to VBAC (4.61\%) group. This was not statistically significant $(\mathrm{p}=0.07)^{6,10,14,15}$
Table 11: APGAR score $<7$ requiring NICU admissions.

\begin{tabular}{|lllll|}
\hline & $\begin{array}{l}\text { Dickinson } \\
\text { et }^{\mathbf{a l}^{6}}\end{array}$ & $\begin{array}{l}\text { Iyer } \\
\text { et al }\end{array}$ & $\begin{array}{l}\text { Gordon } \\
\text { et }^{\mathbf{1 4}} \mathbf{1 4}^{\mathbf{1 4}}\end{array}$ & $\begin{array}{l}\text { Present } \\
\text { study }\end{array}$ \\
\hline $\begin{array}{l}\text { VBAC } \\
(\%)\end{array}$ & 2.40 & 2.90 & 0.68 & 4.61 \\
\hline
\end{tabular}

\section{CONCLUSION}

With the increasing trend of caesarean sections there has been a general awareness to reduce the caesarean section rate. Since the commonest indication for all caesarean sections is repeat caesarean section, there has been various arguments against elective repeat caesarean section for previous LSCS. A trial for vaginal delivery after one caesarean section should be encouraged in women provided no obstetric contraindication exists. Most of the studies have documented safety of trial of labour and VBAC regarding maternal and foetal outcome. Confining to the objectives and results of our study, we will conclude that trial of labour should be encouraged in women with one previous LSCS.

Funding: No funding sources

Conflict of interest: None declared

Ethical approval: The study was approved by the Institutional Ethics Committee

\section{REFERENCES}

1. Arulkumaran S, Ratnam SS, Rao BK. The management of labour. 3rd ed. India: Orient Blackswan; 2014.

2. Myerscough PR. Munro Kerr's operative obstetrics. 13th ed. India: All India Traveller Book Seller; 2019.

3. Cunningham FG, Gant NF, Leveno KJ, Gilstrap LC, Hauth JC, Wenstrom KD. Williams obstetrics. 25th ed. United States: Mc Graw-Hill; 2018.

4. Krishna U, Tank DK, Daftary S. Pregnancy at riskcurrent concept . 4th ed. India: Jaypee publisher; 2004.

5. Mark BL. Vaginal birth after caesarean delivery. Am J Obstet Gynecol. 2000;289:128-40.

6. Gabbe GS, Niebyl RJ, Simpson JL. Obstetricsnormal and problem pregnancies.7th ed. United Kingdom: Churchill Livingstone; 2017.

7. Demianczuk NN, Hunter DJ, Taylor DW. Trial of labour after previous cesarean section. Prognostic indicators of outcome. Am J Obstet Gynaecol. 1982; 142:640-2.

8. Agarwal A, Gupta HP, Anand S, Das K. Vaginal birth after caesarean-A partographic analysis. J Obst Gyn India. 2002;52:85-9.

9. Martin JN, Harris BA, Huddleston JF, Morrison JC, Propst MG, Wser WL, et al. Vaginal delivery following previous caesarean birth. Am J Obstet Gynecol. 1983;146:255-62. 
10. Iyer S, Handa PR, Basu SB. Delivery after one previous caesarean section-one year prospective study. J obst Gyn India. 2001;51:51-4.

11. Elkousy MA, Sammel M, Stevens E, Peipert JF, Macones G. The effect of birth weight on vaginal birth after caesarean delivery success rate. Am J Obstet Gynecol. 2003;188:824-30.

12. Hibbard JU, Ismail MA, Wang Y, Te C, Karrison T, Ismail MA. Failed vaginal birth after a cesarean section: how risky is it? Maternal morbidity. Am J Obstet Gynecol. 2001;184(7):1365-71.

13. Landon MB, Hauth JC, Leveno KJ, atherine YS, Sharon L, Michael WV, et al. Maternal and perinatal outcomes associated with a trial of labor after prior cesarean delivery. N Engl J Med. 2004;351:2581-9.

14. Smith GCS, Pell JP, Cameron AD, Dobbie R. Risk of perinatal death associated with labour after previous caesarean delivery in uncomplicated term pregnancies. J Am Med Assoc. 2002;87:2684-90.

15. Bujold E, Gauthier RJ. Neonatal morbidity associated with uterine rupture: what are the risk factors? Am J Obstet Gynecol. 2002;186:311-4.

16. Brein NO. Uterine rupture during VBAC trial of labour: risk factors and foetal Response. J Midwifery Wom Health. 2013;249-57.

Cite this article as: Shivanna AK, Spandana $S$, Vaidya R. The Clinical study of vaginal birth after caesarean section. Int J Reprod Contracept Obstet Gynecol 2020;9:4855-9. 